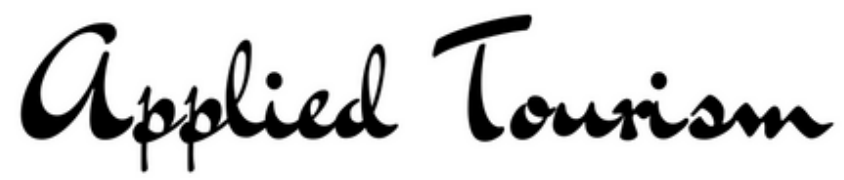 行

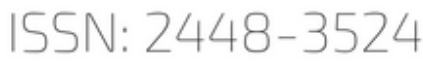 \\ v. $1-\mathrm{n} 2-2016-115-133$ \\ UNIVNLI
}

\section{O ENSINO DOS SABERES DA CULINÁRIA REGIONAL: EXPERIÊNCIA DOCENTE NA AMAZÔNIA PARAENSE NO MUNICÍPIO DE VIGIA}

\section{TEACHING THE KNOWLEDGE OF REGIONAL CUISINE: TEACHING EXPERIENCE IN VIGIA DE NAZARÉ, AMAZON}

\author{
Maraísa Andrade de CAstro - Mestranda do Programa de Pós-graduação em Turismo \\ Escola de Artes, Ciências e Humanidades da Universidade de São Paulo. E-mail: maraisa. \\ andrade@usp.br \\ Cleber Augusto Trindade Castro - Doutorando do Programa de Pós-graduação em Turismo \\ Universidade Federal do Rio Grande do Norte. E-mail: cleber.castro@hotmail.com \\ Debora Cordeiro Braga - Doutora em Ciência da Comunicação \\ Escola de Comunicação e Artes da Universidade de São Paulo. E-mail: bragadc@usp.br
}

Recebido/Received: 16 junho/june 2015. Aprovação/Approval: 06 maio/may 2016

DOI: $10.14210 /$ at.v1n2.p115-133

RESUMO: Este artigo trata-se de um relato de experiência docente vivenciada no Instituto Federal de Educação, Ciência e Tecnologia do Pará, Polo Avançado de Vigia de Nazaré, no processo de planejamento e ministração da disciplina Saberes da Culinária Regional para o Curso Técnico Subsequente em Turismo e Hospitalidade, cujo projeto pedagógico experimental, baseado na metodologia da alternância, adaptado de um modelo da educação rural, teve sua estrutura curricular organizada via temas geradores, conforme a proposta freireana de educação, que prevê a abordagem do conhecimento científico através dos saberes empíricos dos estudantes. Por
ABSTRACT: This article describes an experience which has taken place at the Federal Institute of Education, Science and Technology of Pará, in Vigia de Nazaré, PA, in the process of planning and teaching the subject Knowledge of Regional Cuisine, in the Technical Course in Tourism and Hospitality; the experimental pedagogical project is based on the pedagogy of alternation, adapted from a model of rural education. The curriculum was driven by generative themes, according to Freire (1996), in which scientific knowledge emerges from the student's life experiences. The main content of the course was developed through a survey on students' 
meio do levantamento dos hábitos alimentares dos discentes e de entrevistas com idosos da comunidade, o conteúdo central da disciplina foi desenvolvido, e após leituras de textos, visitas técnicas e atividades práticas e lúdicas, os futuros técnicos sugeriram proposições para valorização da culinária típica da região, e posteriormente realizaram um evento objetivando sensibilizar o empresariado sobre essa questão. $O$ artigo tem como objetivo apresentar uma abordagem de ensino temática diferenciada que pode contribuir para o aprimoramento das práticas de ensino em qualquer instância, assim como inspirar docentes para elaboração de planos de aula criativos. Dentre os resultados obtidos, destaca-se a reflexão sobre as modificações nos hábitos alimentares da comunidade.

Palavras-chave: Ensino técnico. Hábitos alimentares. Culinária regional.

\section{INTRODUÇÃO}

A experiência de ensino/aprendizagem nesse texto relatada foi vivenciada no mês de fevereiro do ano de 2012 no decorrer do trabalho docente no Polo Avançado de Vigia de Nazaré do Instituto Federal de Educação, Ciência e Tecnologia do Pará (IFPA), situado na cidade de Vigia-PA, durante o planejamento e ministração da disciplina Saberes da Culinária Regional.

O componente curricular, antes denominado disciplina, integra o percurso formativo, anteriormente denominado matriz curricular do Curso Técnico Subsequente em Turismo e Hospitalidade, curso experimental em vista de sua abrangência e proposta curricular, não compondo ainda 0 eixo Hospitalidade e Lazer do Catálogo Nacional de Cursos Técnicos do Ministério da Educação (MEC), e diferenciado de acordo com sua base curricular organizada via temas geradores na perspectiva freireana de educação, articulado pela metodologia da alternância pedagógica.

Diante do contexto cultural - histórico de formação, manifestações artísticas, religiosas e folclóricas - e das características naturais da região - rios, igarapés, mangues e floresta o incentivo ao desenvolvimento da atividade turística da região por meio da formação técnica qualificada foi suscitada pelo IFPA na decisão da oferta de um novo curso. O IFPA instalou-se no ano de 2010 na cidade, dando início aos seus três primeiros cursos no ano de 2011, sendo eles: Informática, Recursos eating habits and interviews with community elders; after some readings, technical visits and practical and recreational activities, the future technicians put forward suggestions to promote the local cuisine, and afterwards they held an event to raise awareness of this issue among the business community. The article aims to present a differentiated themeteaching approach which can contribute to the improvement of teaching practices at any level, as well as to inspire creative lesson plans. From the results, it stands out the changes in the community's eating habits.

Keywords: Technical Education, eating habits, regional cuisine

\section{INTRODUCTION}

The teaching-learning experience described in this paper has occurred in February 2012, at the Polo Avançado de Vigia de Nazaré of the Federal Institute of Education, Science and Technology, Pará - Brazil (FIPA), located in the city of Vigia, PA, throughout the planning and delivery of teaching of the subject Knowledge of Regional Cuisine.

The curricular component, formerly called subject, is part of the training path, formerly known as the curriculum of the Technical Course in Tourism and Hospitality, an experimental course in view of its scope and curriculum proposal, not yet comprising the component of Tourism, Hospitality and Leisure of the National Catalogue of Technical Courses of the Ministry of Education; differentiated according to its curricular base organized through generative themes, in Freire's (1996) perspective, and using the pedagogy of alternation.

Given the cultural context - training background, art, religious and folk expressions - and the natural features of the region rivers, streams, wetlands and forest - the incentive for the development of tourism in the region, through qualified technical training, came from the new course offered by FIPA. It was established in the city in 2010, and in the following year the first three courses started: Informatics, Fishery Resources and Tourism and Hospitality; these are subsequent technical-level programs.

The Pedagogical Proposal of the Course (PPC) in Tourism and Hospitality presents as the social purpose of the Institute "to promote humanistic scientific and technological education, and aimed at educating critical and reflective professional citizen, technically and ethically committed to the social, political and 
Pesqueiros e Turismo e Hospitalidade, todos na modalidade técnica subsequente.

A Proposta Pedagógica do Curso (PPC) de Turismo e Hospitalidade apresenta como função social do Instituto "promover educação científico-tecnológico-humanística, visando à formação do profissional-cidadão críticoreflexivo, técnica e eticamente comprometida com as transformações sociais, políticas e culturais." (IFPA, 2012, p. 4). E como compromisso do Polo:

\section{[...] uma formação profissional e tecnológica contextualizada, que considere e trabalhe com a cultura, os modos de produzir a existência material e social dos sujeitos na região e, a partir daí, resgate e socialize os conhecimentos historicamente acumulados pelas populações locais, estimulando o exercício teórico-prático, no sentido de permitir a compreensão crítica do conhecimento da ciência, cultura, técnica e tecnologia, como elementos indissociáveis e integrantes da prática humana, possibilitando aos indivíduos se verem e se afirmarem como sujeitos de conhecimentos e fazerem uso social destes em um projeto de emancipação/ desenvolvimento regional. (IFPA, 2012, p. 10).}

Pautando-se nessas diretrizes, 0 percurso formativo do curso em questão foi construído, e seguindo a perspectiva de ensino/aprendizagem freireana, em que para Freire (1996) "não há ensino sem pesquisa e pesquisa sem ensino" (p. 29), e do "por que não estabelecer uma "intimidade" entre os saberes curriculares fundamentais aos alunos e a experiência social que eles têm como indivíduo?" (p. 30), os professores foram orientados e incentivados a construírem seus planos de aula para as disciplinas.

Voltando-se especificamente para o componente curricular Saberes da Culinária Regional, toda a proposição de atividades nele contida foi executada e baseou-se nos direcionamentos acima apontados, embora a metodologia de condução das aulas tenha sido definida livremente pela docente. Observase que cada "dia" de aula correspondeu a 4 horas/aula, sendo a duração média de 50 minutos cada, totalizando 20 horas/aula de atividades. No total, participaram do processo 39 discentes.

Dentre os principais objetivos das atividades promovidas estavam o levantamento dos conhecimentos prévios dos alunos sobre cultural transformations". (IFPA, 2012, p. 4). And as the commitment of the Vigia, PA unit:

\begin{abstract}
[...] A professional and technological training in context which considers and works with culture, ways of producing material and social existence of individuals in the region and, from there, recovers and socializes the knowledge historically acquired by local people, encouraging a theoretical and practical exercise, in order to enable the critical understanding of scientific, cultural, technical and technological knowledge, as inseparable elements and part of human practice, enabling individuals to see and assert themselves as agents of knowledge and making social use of these on a project of emancipation and regional development. (IFPA, 2012, p. 10).
\end{abstract}

The training path of the course in question is based on these guidelines and was built following the teaching perspective of Freire (1996) that "there is no teaching without research and research without teaching" ( $p$. 29), and "why not establish an 'intimacy' between the fundamental curricular knowledge and the social experience students have as individuals?" (p.30), teachers were instructed and encouraged to build their lesson plans for the subjects.

Regarding the curricular component Knowledge of Regional Cuisine, the activities that have been proposed were based on the aforementioned directions, although the class methodology had been set freely by the teacher. It was observed a four-hour class day, of approximately 50 minutes each class, amounting to 20 hours/ class activities. A total of 39 students participated in the process.

Among the main objectives of the activities carried out were the assessment of students' prior knowledge on the subject and their eating habits, the gathering of information about the community's eating habits and the technical evaluation of the local situation; in all activities time for further discussion was considered in order to provide a reflection on the means and actions that aimed at the enhancement of typical regional cuisine.

BACKGROUND

Research setting

The study was conducted in Vigia, a city of approximately 47,889 inhabitants according to the 2010 
o tema e seus costumes alimentares, a coleta de informações acerca dos hábitos alimentares da comunidade em que viviam e a apreciação técnica da realidade local; todas as atividades tiveram tempo disponível para discussão posterior, a fim de proporcionar a reflexão sobre meios e ações que visassem a valorização da culinária típica regional.

\section{CONTEXTUALIZAÇÃo}

\section{Cenário da pesquisa}

A cidade de Vigia, onde o trabalho foi desenvolvido, possui aproximadamente 47.889 habitantes de acordo com os dados demográficos do Censo 2010, elaborado pelo Instituto Brasileiro de Geografia e Estatística (IBGE). Geograficamente faz parte da microrregião do salgado, compondo a mesorregião do nordeste paraense, que por sua vez integra a Amazônia Legal, a figura 1 traz um Mapa de localização de Vigia-PA (Mourão, Pinheiro \& Lucena, 2007) presente no Anexo.

De acordo com os dados da Secretaria de Estado, Planejamento, Orçamento e Finanças (SEPOF) em conjunto com o Instituto de Desenvolvimento Econômico, Social e Ambiental do Pará (IDESP) no documento Estatística Municipal (2011), a ocupação do território referente ao município em questão é referida aos índios Tupinambás, e sua colonização teria ocorrido entre 1645 e 1654, constituída historicamente para ser um posto de vigilância costeira nesse período.

$\mathrm{Na}$ atualidade a cidade ribeirinha resguarda culturalmente diversas expressões, com representação no cenário musical, em razão da existência de três bandas musicais; na literatura, fato registrado pela manutenção de um acervo bibliográfico na sede da Sociedade Literária e Beneficente 5 de agosto; da manutenção de um museu municipal, de arraiais juninos, festividades santas, comemoração carnavalesca tradicional e diversas igrejas históricas.

Vale ressaltar que acerca do ano de fundação da cidade há inúmeras controvérsias, existem historiadores que ainda tentam remontar a história de formação do município por meio da pesquisa de documentos antigos. Popularmente comemora-se o aniversário da cidade no dia 6 de janeiro, sendo feriado
Census (Brazilian Institute of Geography and Statistics - IBGE). Geographically, it is part of the micro-region of Salgado, included in the mesoregion of Northeastern Pará, which in turn is part of the Brazilian Amazon; Figure 1 , in appendix, depicts the location of Vigia, PA (Mourão, Pinheiro \& Lucena, 2007).

According to data from the State Secretariat of Planning, Budget and Finance of Pará as well as from the Economic, Social and Environmental Development Institute of Pará, in the document Municipal Statistics (2011), the occupation of the territory related to the municipality in question is referred to Tupinambá Indians. The colonization would have occurred between 1645 and 1654 , and historically it was established to be a coastal surveillance zone, in that period.

Nowadays, the river town exhibits many cultural expressions represented in the music scene by three musical bands; in literature, by the maintenance of a bibliographic collection at the headquarters of the Literary and Benevolent Society 5 de Agosto; the maintenance of a municipal museum, holy festivities, a traditional carnival celebration and several historic churches.

It is noteworthy that the exact year of the foundation of the city is debated; there are historians who are still trying to determine it resorting to old documents. Commonly, it is considered that Vigia, PA was founded on January 6, 1616, when it is celebrated the anniversary of the city (Wikipédia, 2014).

The periods of the year with the highest record of visitors, according to data of Municipal Statistics (2011), are prompt by events; standing out, according to the training path of the Subsequent Technical Course in Tourism and Hospitality and given the lack of governmental data, as the two largest: the Carnival and the Círio, this occurs in the second weekend of September and it is a popular religious manifestation in the state of Pará.

\section{THE PLANNING OF THE SUBJECT}

In the process of building the training path integrating the PPC, guided by the National Tourism Plan and the Pará Tourism Development Plan, and considering the cultural and environmental features of the region, many subjects were suggested by the group of teachers who worked in its preparation, which were based in the educational projects of courses of the axis Tourism, Hospitality and Leisure existing in other campuses of the FIPA, such as Accommodation \& Events, being that this information is absent in that document.

After the beginning of the classes, during the execution of Cycle I, denominated situation 
municipal, e de acordo com informações da Wikipédia (2014), enciclopédia virtual com livre autoria, fato também constatado empiricamente junto aos alunos, comerciantes e funcionários públicos, o ano de fundação seria 1616.

Há controvérsias também com relação à distância em quilômetros do município em relação à capital Belém-PA, dada a necessidade de um referencial para uma adoção numérica, de acordo com a fonte anteriormente citada, considera-se $77 \mathrm{~km}$, todavia, acredita-se que para essa distância, a referência seja o limite de ambos os municípios e não os marcos zero das cidades.

Os períodos do ano com maior registro de visitantes acontecem em decorrência de eventos, conforme o documento Estatística Municipal (2011), destacando-se, de acordo com o percurso formativo do curso técnico subsequente em Turismo e Hospitalidade, em vista da ausência de dados na instância governamental, como os dois maiores: Carnaval e o Círio de Nossa Senhora de Nazaré; esse último ocorre no segundo final de semana do mês de setembro e trata-se de uma manifestação religiosa bastante popular no estado do Pará.

\section{PLANEJAMENTO DA DISCIPLINA}

No processo de construção do percurso formativo que integra a PPC, esse pautado no Plano Nacional de Turismo (PNT) e no Plano de Desenvolvimento Turístico do Estado do Pará, e considerando-se as características culturais e ambientais da região, diversas disciplinas foram sugeridas pelo grupo de professores que trabalharam em sua elaboração, que se basearam para isso nos projetos pedagógicos de cursos do eixo Turismo, Hospitalidade e Lazer em vigor nos outros campi do IFPA, como Hospedagem e Eventos, sendo que essa informação não está expressa no documento referido documento.

Após o início das aulas, durante a execução do Ciclo I, denominado Situação do turismo e da hospitalidade na microrregião do Salgado, os discentes desenvolveram pesquisas bibliográficas, reunindo informações acerca de diversos aspectos do município, tanto na zona urbana quanto na rural, englobando histórico, atividades econômicas desenvolvidas, manifestações culturais, eventos, equipamentos turísticos e os potenciais turísticos tangíveis e intangíveis of Tourism and Hospitality in the Micro-region of Salgado, students have done literature research, gathering information about various aspects of the city, both in urban and in rural areas, encompassing history, economic activities, cultural events, tourist facilities and the tangible and intangible tourist assets; given that research, the group of teachers prepared the training path of the course, reorganizing the curriculum, suggesting new components, and removing those which did not meet the students' expectations.

Silva (2013) outlines the process of building a theme-based curriculum, justifying the need for an interdisciplinary education program that considers the union between popular and scientific knowledge to promote a real critical educational practice. At another point, the author also argues that the mere reproduction of content, imposed by textbooks, generates artificial criticism in the analysis of reality.

Under these guidelines, teachers elected significant lines, passages considered relevant by the recurrence within the texts produced by the students; which were afterwards grouped by theme, and then the opposites themes were defined, resulting from the reconstruction of those lines from a scientific perspective.

Looking into the planning of the curriculum component Regional Cuisine Knowledge, the three more significant phrases, extracted from APPENDIX I: Knowledge Networks of the Course in Tourism and Hospitality of PPC (IFPA, 2012) were: "There is a lack of cuisine which explore more flavors from the region" (this being chosen as a generative theme), "we have numerous species of fish, but they don't appear in the daily menus of restaurants, deterring tourists" and "the cuisine is still not very well known, which is a shame. The flagship is the gurijuba fish, and its various dishes." (p. 43).

Based on these statements, the opposite themes were presented: we have diversity of fish in the region, although the restaurants do not offer varied species. We believe that the flavors of the region can be exploited through traditional recipes and culinary re-invention, keeping up with the changes of contemporary eating habits. The opposite theme is not registered in the PPC, it was drawn up during a planning meeting, built to line the speeches of teachers who would teach classes that encompassed the same generative theme.

At the end of that generative theme, after the teaching of the five subjects, there was community time, a part of the pedagogy of 
locais; em posse dos trabalhos, o grupo de professores elaborou o percurso formativo do curso, reorganizando estruturalmente os componentes curriculares, sugerindo novos, e retirando da proposta inicial os que não condiziam com as expectativas dos estudantes.

Silva (2013) esquematiza o processo de construção de currículo via tema gerador, justificando a necessidade de um projeto pedagógico interdisciplinar, que considere a união entre os saberes popular e científico para promoção de uma real prática educacional crítica. Em outro momento, o autor também defende que a mera reprodução de conteúdo imposto por livros didáticos gera a artificialidade crítica na análise da realidade.

Sob essas orientações, os docentes elegeram falas significativas, trechos considerados relevantes pela recorrência, dentro dos textos produzidos pelos discentes, que depois foram agrupados por temática, então foram definidos os contratemas, fruto da reconstrução daquelas falas sob a visão científica.

Voltando-se para o planejamento do componente curricular Saberes da Culinária Regional, as três falas significativas, extraídas do ANEXO I: Teias/Redes de Conhecimento do Curso de Turismo e Hospitalidade da PPC (IFPA, 2012) foram: "falta culinária que explore mais os sabores da região" (sendo essa eleita como tema gerador), "temos peixes de inúmeras espécies, mas a falta de ofertas diária nos restaurantes afasta os turistas", e "a culinária ainda não é muito conhecida, o que é uma pena. O carro-chefe é a gurijuba ${ }^{1}$, que dela podemos saborear diversos pratos." (p. 43).

Baseando-se nelas, elaborou-se como contratema: temos diversidade de peixes na região, ainda que os restaurantes não ofertem variadas espécies. Acreditamos que os sabores da região possam ser explorados, tanto por meio de receitas tradicionais quanto por inovações culinárias que acompanham as alterações de hábitos alimentares contemporâneos. O contratema não está registrado na PPC, foi elaborado durante uma reunião de planejamento docente, construído para alinhar os discursos dos professores que ministrariam aulas nos componentes curriculares que englobavam o mesmo tema gerador.

Ao final do referido tema gerador, após as cinco disciplinas ministradas, organizouse um tempo comunidade, parte integrante alternation, which works as a closing of certain steps; the students return to their places of residence to put into practice or improve their activities according to the scientific knowledge they have learnt in school time.

In the studied case, the proposal was an intervention event: 1st Gastronomic Competition Flavors of Vigia; the students have received financial support to develop the project and a logo was created for this event. Figure 2 shows the logo of the 1st Gastronomic Competition Flavors of Vigia.

Following Teixeira, Bernartt and Trindade (2008), the methodology of alternation between school time and community time in Vigia had been adapted, given that the return to the community, where the socio-professional experience would occur, did not exempt the students from going to the Institute, in view of the proposed activities. The authors state that this pedagogy has many examples in Brazil; they present a quantitative overview of the academic approach of this method, however the frequent examples refers to education in rural areas.

The Competition organized by students, with the help of teachers, had the participation of local Food and Drink Sector entrepreneurs as jurors. On the occasion, menus were presented with innovative recipe suggestions using regional produce and supplies and a degustation menu was offered.

\section{DYNAMIC OF THE CLASS}

On the first day of the curriculum component, February 13, 2012, the students present were asked about their eating habits and food preferences; their responses were recorded by the teacher for future study. After presenting the plan for the next classes and watching some official tourist videos, the students received the first assessment activity; it consisted of an interview script containing three questions prepared by the teacher and they were to come up with one or two more questions that they considered relevant during the interviews to be done with people over the age of 60 , acquainted or not, who lived in the municipality.

Giving their number, students were divided into eight three-person teams to applicate the interview script. Basically, the questions were intended to raise information about the respondents' knowledge of their community's 
da pedagogia da alternância, que prevê como fechamento de determinadas etapas, que os estudantes voltem aos seus locais de moradia para colocar em prática ou aprimorar seus afazeres após apreensão de conhecimento científico previsto no tempo escola.

No caso abordado, a proposta foi um evento de intervenção, intitulado: I Concurso Gastronômico Vigia dos Sabores; na ocasião, os alunos receberam auxílio estudantil para desenvolver o projeto e uma logomarca foi criada para o evento. A figura 2 traz como ilustração a logomarca do I Concurso Gastronômico Vigia dos Sabores (anexo), e compõem o arquivo pessoal da docente do componente curricular.

Pautando-se em Teixeira, Bernartt e Trindade (2008), pode-se afirmar que a metodologia da alternância, entre tempo escola e tempo comunidade, implantada no Polo Vigia de Nazaré acontece de forma adaptada, visto que o tempo de retorno para comunidade, onde ocorreria a vivência socioprofissional, ña eximia, no exemplo apresentado, o acesso dos discentes ao Instituto, em vista das atividades propostas. Os autores expõem que essa pedagogia, possui diversos exemplos no Brasil, inclusive apresentam um panorama quantitativo sobre a abordagem acadêmica desse método, todavia os exemplos frequentes são resguardados a educação do campo, trabalhada principalmente em zonas rurais.

O Concurso promovido pelos discentes, com auxílio dos professores do eixo, contou com a participação, como jurados, de empresários do setor de Alimentos e Bebidas da cidade. Na ocasião foram apresentados cardápios com sugestões de receitas inovadoras utilizando ingredientes e insumos da região e ofereceu-se degustação de todos os pratos apresentados nos cardápios.

\section{DINÂMICA DAS AULAS}

No primeiro dia de aula do componente curricular, $13 / 02 / 2012$, os discentes presentes foram indagados acerca de seus hábitos e preferências alimentares, suas respostas foram registradas pela docente para abordagem futura. Após apresentação do plano para as próximas aulas, e de apreciarem alguns vídeos turísticos institucionais, receberam como primeira atividade avaliativa do componente curricular, um roteiro base eating habits. Students were also encouraged to bring to class a recipe they liked, in an A4 sheet decorated at will.

Next day the lesson began with a playful activity. The recipes brought by the students were glued on a string that was hanging in the room like a clothesline, thus creating a decorative garland of recipes. After collecting the responses obtained in the interviews, written by the students themselves, they had the chance to report their experiences as interviewers and their impressions about what they have heard and registered. Altogether, nine interviews were conducted. Then, the lesson plan was resumed.

On February 15, 2012, during the class time the fish and meat municipal markets, and the fresh fruit and vegetables street market were visited. It is worth noting that in Vigia, as well as in the state capital, the street markets are permanent and, generally, opened Monday to Saturday. After the visits, the students expressed their perceptions about what they have observed in the visits; the main issue raised was the poor sanitary condition of all markets.

The day after, the teacher presented examples of markets like Ver-o-Peso Market in Belém, PA; the Municipal Market of São Paulo, SP; and the market Modelo in Salvador, BA, to which several tour guides suggest a visit. This led everyone to reflect on how these facilities, initially designed only to sell perishable products, gain new meaning, becoming tourist attraction sites. Then the class continued following the plan.

In the last day of school, on February 27, 2012, students were divided into teams - five eight-member teams, on average - and they took dishes prepared with typical ingredients of the region, but with recipes created or recovered from the interviews, but that most of the class did not know, for example, the "crab in coconut juice", depicted in Figure 3 in the Appendix. And after tasting they were asked about alternatives that might put forward in order to enhance the regional cuisine.

At the end of class, the attending students assessed the development of the curricular component, through the pedagogical model of dynamic assessment proposed by Berkenbrock (2009) which consists of answering concisely three questions: "what good?" "what a pity?" and "what about it?"; adapted by the teacher for the occasion including two new questions: "most liked activity" and "least liked activity" (p. 146). 
de entrevista contendo três perguntas elaboradas pela professora e a missão de elaboração de mais uma ou duas questões que julgassem relevantes durante a aplicação, para realizarem entrevistas com pessoas com idade superior a 60 anos, que conhecessem ou não, mas que fossem residentes do município seja da zona rural ou urbana.

De acordo com o número de presentes, estabeleceu-se a formação de trios para procederem com a aplicação do roteiro de entrevista, formando-se oito equipes. Basicamente as perguntas levantariam informações acerca dos saberes relativos aos costumes alimentares da comunidade em que viviam sob a perspectiva dos entrevistados. Os alunos também foram incentivados a levarem a receita de alguma comida que apreciassem para o próximo dia de aula, em folha de formato A4 decorada de maneira livre.

No dia seguinte, a aula iniciou com uma atividade lúdica, as receitas trazidas pelos alunos foram coladas em um barbante, que foi pendurado na sala como um varal, assim criou-se um cordel decorativo de receitas. Depois da coleta das respostas obtidas nas entrevistas, redigidas pelos próprios discentes, livremente os mesmos tiveram a oportunidade de relatar suas experiências como entrevistadores e suas impressões acerca das respostas ouvidas e registradas. Ao todo foram realizadas nove entrevistas. Então se procedeu com a ministração de conteúdo didático previsto em ementa.

No dia 15/02/2012, no horário de aula, procedeu-se uma visita técnica aos mercados municipais de peixe e carne, e a feira livre de hortifrutigranjeiros da cidade. Vale observar, que em Vigia, assim como na capital do estado, as feiras são permanentes e funcionam, em geral, de segunda a sábado. Após as visitas, os discentes expuseram suas percepções acerca do que observaram nos espaços visitados, nesse momento, o principal assunto levantado foi a má condição sanitária de todos.

No dia posterior, a professora apresentou exemplos de mercados, como Mercado do Vero-Peso em Belém-PA, o Mercado Municipal de São Paulo-SP e Mercado Modelo de Salvador$B A$, que possuem recomendação de visita em diversos guias turísticos. Isso levou a todos a refletirem de que forma esses equipamentos, inicialmente moldados para comercialização de alimentos perecíveis, tomam resignificação, tornando-se pontos de visitação turística. Em seguida, continuou-se a sequência de conteúdo recomendado na ementa.
Following, the methodology used for the construction of this article is presented, as well as the results from the first evaluation activity of the curricular component.

\section{METHODOLOGY}

In terms of methodology, a literature research was done to provide a conceptual framework to the pedagogy and methodology of the Pedagogical Proposal Course in question; the authors lacked in-depth knowledge regarding this topic, as in their Bachelor's Degree in Tourism there is no such related subject. And, also the literature provided an understanding on the construction of a generative theme-oriented pedagogical project, since the teacher just took part in the PPC review with the classes already in progress, from the second generative theme of the Cycle II - Productive Arrangement of Tourism and Hospitality in the Micro-region of Salgado.

The participation in the workshops offered to teachers and the integration as a member in the collegial coordination of the course, while working at FIPA, brought valuable knowledge about this theme, and made possible to get closer to the students and their life stories.

For the purpose of this article, the experience was described to present a teaching situation that has been approved by the students regarding the methodology used during the classes; also, the lively and incontext approach to the themes were factors highlighted in the evaluation of the curricular component, held on the last day of school.

The results were achieved through the analysis of the answers to the interviews, transcribed by the students; and also, by the analysis of the responses recorded by the teacher in the classroom, regarding the students' food preferences and eating habits. Those elements are considered key to reveal the assertiveness of the experienced teaching method. To depict the results presented as follow, all material produced during the experience was revised for the construction of the descriptive and analytical text which is the basis for defending the relevance of the adopted practice.

It is necessary to point out that this analysis was not written down previously, the data from the interviews, as well as the observation and reflections drawn were reserved for the 
Para o último dia de aula, em 27/02/2012, os discentes, divididos em grupos - cinco equipes com média de oito integrantes - levaram pratos elaborados a partir de ingredientes típicos da região, mas com receitas criadas ou resgatadas nas entrevistas, mas que a maioria da turma não conhecia, como exemplo, o "caranguejo ao sumo do coco" ilustrada pela figura 3 do Anexo cuja fonte é o arquivo pessoal da docente do componente curricular.

E após degustação, foram indagados acerca de alternativas que poderiam propor em prol da valorização da culinária regional.

Ao final da aula, os estudantes presentes avaliaram o desenvolvimento do componente curricular, através do modelo pedagógico de dinâmica de avaliação proposta por Berkenbrock (2009) que consiste na resposta de forma concisa a três questões: "que bom?", "que pena?" e "que tal?"; adaptado pela docente para ocasião incluindo duas novas questões: "atividade que mais gostou?" e "atividade que menos gostou?" (p. 146).

Na sequência apresenta-se a metodologia adotada para construção desse artigo e os resultados obtidos através da primeira atividade avaliativa do componente curricular.

\section{METODOLOGIA}

Como metodologia adotou-se o levantamento bibliográfico que respaldasse a abordagem conceitual da pedagogia e metodologia da PPC do curso em questão, visto que na formação dos autores no Bacharelado em Turismo não há disciplina com esse direcionamento. Também para entender a construção de um projeto pedagógico pautado em temas geradores, já que a docente participou apenas da revisão da PPC com as aulas em andamento, a partir do segundo tema gerador do Ciclo II - Arranjo produtivo do turismo e da hospitalidade na microrregião do Salgado.

A participação em oficinas ofertadas para os professores do Polo e a integração como membro na coordenação colegiada do curso, durante o período de trabalho no IFPA, também serviram de grande valia no processo de apreensão de conhecimento sobre essa temática, e de aproximação com os discentes e suas histórias de vida.

Para composição deste artigo, optou-se pelo relato de experiência com a finalidade discussions in the classroom, thus ensuring the original character of this.

\section{RESULTS}

\section{Interviews}

The respondents are identified by sequential numbering and their age: interviewee 1: 78 years old; interviewee 2: 78 years old; interviewee 3: 72 years old; interviewee 4: 66 years old; interviewee 5: 69 years old; interviewee 6: 96 years old; interviewee 7: 71 years old; interviewee 8: 61 years old; and interviewee 9: 69 years old.

Regarding the first question of the interview script "Do you notice any changes in today's food compared to the past?", briefly, the following answers were obtained: interviewee 1 reported that in the past, fish consumption was substantially higher; chicken and beef were scarce at the table; interviewee 2 considered that food in the past was more "natural", in relation to condiments, and also raised the issue of animal feeding, such as cattle and chicken, which these days eat animal feed and, formerly, were fed with produce from the farms; interviewee 3 responded that before people ate more fish, meat was reserved for Sundays; he noted the fact that no longer exists the fear of eating acai berries with other fruits; and also reported that before people ate more game meat, which would be currently prohibited by the Brazilian Institute of Environment and Renewable Natural Resources; interviewee 4 reported that there was not food such as lasagna and pasta and red meat was expensive, thus the main source of food was fish, due to its abundance in the region; interviewee 5 stated that they ate more crab, there was considerable consumption of pork and backyard chickens; interviewee 6 said that before food came from agriculture and fishing, and nowadays canned food is consumed; interviewee 7 said that in the past they ate more salted meats, cured for preservation; interviewee 8 said formerly they grew vegetables and raised animals on a small scale, in a more "natural" way; interviewee 9 reported that today we eat too much fat and that despite food is easier to access, it is less healthy.

With respect to these reports, it is clear that being a riverside city, the fish was abundant in the diet, a possible cause for the decrease 
de apresentar uma vivência docente que obteve aprovação dos estudantes com relação à metodologia adotada no decorrer das aulas e a forma dinâmica e contextualizada da abordagem do tema, fatores evidenciados nas respostas registradas nas fichas da dinâmica de avaliação do componente curricular realizada no último dia de aula.

Como método de construção dos resultados, optou-se pela análise das respostas dos roteiros de entrevista, transcritas pelos alunos, em paralelo à análise das respostas registradas pela professora, em sala de aula, a respeito dos hábitos e gostos alimentares dos discentes, pois se considera esse conteúdo fundamental para revelar a assertividade do método didático experienciado. Para expor os resultados apresentados na sequência, todo material produzido durante a vivência foi revisado para a construção do texto descritivo e analítico que serve de base para defender a relevância da prática adotada.

Faz-se necessário destacar que essa análise não foi registrada por escrito anteriormente, as informações resultantes das entrevistas, assim como observações constatadas e reflexões traçadas ficaram reservadas às discussões em sala de aula, garantindo assim o caráter original deste.

\section{RESULTADOS}

\section{Entrevistas}

Para apresentação dos entrevistados optou-se por identificá-los através de numeração sequencial e idade, sem exposição de nomes, assim, os entrevistados são: entrevistado 1 - 78 anos; entrevistado 2 - 78 anos; entrevistado 3 - 72 anos; entrevistado 4 - 66 anos; entrevistado 5 - 69 anos; entrevistado 6 - 96 anos; entrevistado $7-71$ anos; entrevistado 8 - 61 anos; e entrevistado $9-69$ anos.

Referindo-se a primeira pergunta do roteiro "O(a) $\mathrm{Sr}(a)$ verifica alguma alteração no tipo de alimentação de hoje com relação à antigamente?", de forma sucinta, obteve-se as seguintes respostas: entrevistado 1 - 78 anos, relatou que no passado o consumo de peixe era consideravelmente maior, frango e carne eram mais difíceis à mesa; entrevistado 2 78 anos, expôs que a comida no pretérito era mais "natural", com relação aos condimentos, in consumption, may be the export. There are several fishing industries in the city, fishing is one of its main economic activities and it ranked second in Pará, in terms of volume of catch, according to the research of Mourão, Pinheiro and Lucena (2007). However, this would have resulted in an increase in the cost of fish due to the external market competition, and in a decrease of residents' buying power. Regarding the mentions to the natural origin of the food consumed in the past, the statements reflect a reality in which the vegetable gardens were usual and the raising of animals for food as opposed to food markets and street fairs; which also reflects the increased consumption of semi-processed, canned or pre-cooked food, as well as the ready-to-use condiments in the preparation of meals. The issue of animal feed stems from the large-scale livestock breeding in an ever shorter period of time.

Interestingly, it was mentioned the "loss of fear" about acai berry consumption in combination with other fruits; culturally there is the belief that when eating acai, the person should not eat any other fruits because of the danger of suffering a congestion or even dying; in fact, people from Pará still have the habit of consuming pure acai berries, or with added sugar or cassava flour or tapioca, even as part of a meal, without mixing it with other fruit, but as a matter of tradition and not worrying about getting sick, despite the elderly's belief about the harmful effects of the combination.

Referring to the second question of the script "Was there some typical food that formerly was eaten and not today?", interviewee 1 cited the cassava bread (a traditional food in the cuisine of the rural area among families that produce manioc flour), and commented that old traditional ethnic food as maniçoba, vatapá and tacacá were dishes reserved for special events or festivities; interviewee 2 said that in the past maniçoba (ground cassava leaf, a basis for the preparation of food) was prepared in the yards of houses for seven days, and today it can be bought pre-cooked; interviewee 3 addressed the same previous issues, and added the fact that tapioca (made from cassava starch), which previously would only be filled with shredded coconut, is today sold with numerous filling flavors; interviewee 4 referred a dish called "chicken head", which was a mixture of egg, salt, chicory and basil (unknown by most students) and cassava flour porridge; interviewee 5 said the duck in tucupi sauce (also considered typical traditional food) 
e também levantou a questão da alimentação dos animais, como gado e frango, que nos dias atuais são alimentados com ração e antes comiam alimentos da roça; entrevistado $3-72$ anos, respondeu que antigamente se comia mais peixe, as demais carnes ficavam reservadas aos domingos, comentou o fato de ter-se "perdido o medo" de ingerir açaí com outros tipos de frutas, e também relatou que se comia mais carne de caça, o que atualmente seria proibido pelo IBAMA (Instituto Brasileiro do Meio Ambiente e dos Recursos Naturais Renováveis); entrevistado $4-66$ anos, relatou que não "existiam" comidas como lasanha e macarronada e que a carne vermelha possuía um alto custo, por isso, a alimentação principal era peixe pela abundância na região; entrevistado 5 - 69 anos, expôs que se comia mais siri, que havia consumo considerável de porco, frango e galinha caipiras criados nos quintais das casas; entrevistado 6 - 96 anos, respondeu que antes a alimentação era baseada na agricultura e na pesca, e hoje em dia se consome muito enlatado; entrevistado 7 - 71 anos, disse que antes se comia mais carnes salgadas, em razão da necessidade de conservação das mesmas; entrevistado 8-61 anos, comentou que antigamente plantavam e criavam mais animais em pequena escala, assim existia um tempo de espera para o consumo de alimentos, que eram mais "naturais"; entrevistado 9 - 69 anos, relatou que na atualidade se come muita gordura e que apesar de ser mais fácil o acesso a compra de comida em estabelecimentos comerciais, a alimentação é menos saudável.

A respeito dos relatos acima expostos, percebe-se que por ser uma cidade ribeirinha, o peixe foi apontado como alimento bastante consumido no passado, uma possível resposta ao decréscimo no consumo, seja a exportação. O município possui diversas indústrias pesqueiras, e resguarda na pesca uma de suas principais atividades econômicas, sendo detentora da segunda colocação no volume da captura de peixes no estado do Pará de acordo com as pesquisas de Mourão, Pinheiro \& Lucena (2007). Entretanto, isso teria ocasionado o aumento no custo do pescado em razão da competição do mercado externo com o interno, o que fez com que muitos moradores perdessem o poder de consumo sobre o peixe por questão financeira.

Com relação à referência sobre a origem natural dos alimentos consumidos no passado, as afirmativas refletem a realidade de que era mais usual o cultivo de hortas e a criação was once more consumed, and, among others, porridge of gurijuba fish roe; interviewee 6 named several fish that were eaten more frequently, commented that cassava was hand pounded, poultry was backyard-raised, and it was easier to find crab and turu (shipworms) to sell; interviewee 7 answered that there is none; interviewee 8 reported that they ate crab and even turu in the coconut juice; and interviewee 9 mentioned the salted gurijuba fish cooked with beans; nowadays, much of the fish is frozen on the boat, make it harder to find it salted.

On the reports above it is registered the food industry impact on eating habits, be it the frozen fish for exports or the production of pre-cooked cassava leafs aiming to decrease the cooking time and make its preparation more convenient. It is noteworthy, that some traditional ethnic dishes were eaten only in special occasions, and today are sold in restaurants and street stalls. It is noteworthy that, although maniçoba and duck in tucupi sauce are traditionally eaten in the Festivity of Círio, traditional dishes are also more consumed out of celebration days.

It was referred the consumption of beiju - kind of bread made with cassava flour but it is known that it is still a common item in the diet of the inhabitants in the rural area. It is believed that the popularization of tapioca and its expansion throughout the country has inspired culinary professionals and gastronomes to create different fillings. The respondent who raised the issue, drawing on the fillings examples written on the form (cheese, chocolate, condensed milk and egg) may not know the immensity of culinary variations for the once simple beiju of tapioca, served plainly with butter or margarine, in the savory version, or with grated coconut and coconut milk, in the sweet.

Regarding the third question of the interview script, "In your view, what are the most consumed foods in the region?", the following responses were obtained: interviewee 1 said meat bought in the supermarket; interviewee 2 responded fish; interviewee 3 cited beef, chicken and, among the fruits, he stressed acai berries; interviewee 4 said fish; interviewee 5 referred more "sophisticated" fish; interviewee 6 responded chicken, beef and beans; interviewee 7 responded acai berries, fish, meat, chicken, beans and rice; interviewee 8 reported beef and chicken; and interviewee 9 said beef and chicken, because they are cheaper than fish. 
de animais de pequeno porte para consumo, em contraponto a atual praticidade de compra dos alimentos em mercados e feiras livres; o que reflete também o aumento da ingestão de produtos semiprontos, enlatados e/ou de preparo rápido, assim como o uso mais frequente de condimentos prontos na preparação das comidas. A questão da inserção de ração na alimentação dos animais reforça a necessidade da "produção" de carnes em larga escala em período de tempo cada vez menor.

Curiosamente levantou-se a "perda do medo" acerca do consumo do açaí em combinação com outras frutas, culturalmente existe o mito de que ao ingerir açaí, o indivíduo não deveria comer diversas outras frutas, pelo perigo de sofrer uma congestão ou até ir a óbito; de fato, o povo paraense tem como hábito consumir o açaí puro ou com adição de açúcar ou farinha de mandioca ou tapioca, até mesmo como parte de uma refeição, todavia sem a mistura direta com frutas, mas por questão de tradição, e não mais pelo receio de passar mal, ainda que os mais idosos acreditem que os efeitos maléficos da combinação do açaí com outras frutas não seja um mito.

Referindo-se a segunda pergunta do roteiro "Existia alguma comida típica que antigamente se comia e hoje não?", as respostas foram: entrevistado 1 - 78 anos, citou o beiju (alimento bastante tradicional na culinária da zona rural dentre as famílias que produzem farinha de mandioca), e comentou que antigamente comidas típicas tradicionais como maniçoba, vatapá e tacacá ficavam mais reservadas às comemorações; entrevistado 2 - 78 anos, expôs que antes a maniçoba era preparada nos quintais das casas durante sete dias, e hoje já vendem a maniva (folha da mandioca moída, base para o preparo da comida) pré-cozida; entrevistado $3-72$ anos, abordou as mesmas questões dos dois entrevistados anteriores, com acréscimo a respeito dos recheios da tapioca (feita da goma da mandioca), que antes seria somente preparada com coco ralado, e hoje são comercializadas com inúmeros sabores; entrevistado 4 - 66 anos, citou uma comida denominada cabeça de galo, que seria a mistura de ovo, sal, chicória e alfavaca (desconhecida pela maioria dos discentes) e o mingau de farinha de mandioca; entrevistado 5 - 69 anos, respondeu que o pato no tucupi (também considerada comida típica tradicional) antes era mais consumido, e, entre outras, mingau
It can be noted that most answers mention the substitution of fish for red meat and chicken, given the ease of access to these foods in city markets, mainly for financial reasons. Even though the city is located on the banks of a river, in the examined case, the price is presented as a limiting factor of food fish consumption for respondents. Empirically, it is observed that the fish price in the region is lower compared to the capital, however, it should be taken into account the purchasing power of the community in question.

\section{EATING HABITS}

Basically, the survey with the students asked: typical favorite food; food they ate more on a daily basis; food they did not eat; and fruit they usually ate. Drawing a parallel between the answers previously presented and the students' reports about their tastes and eating habits, it can be concluded that there was no discrepancy; the majority indicated the daily consumption of beef, chicken, rice and beans; few referred to the consumption of vegetables. Apart from the typical foods mentioned throughout the description, according to the answers of the students, two more are added: rice of Pará and rice with chicken.

With regard to fish, mentioned as a less consumed item due to its increasing cost, it was referred by some students, and in the elderly's interviews, as part of their daily meals. Therefore, it is concluded that fish is still part of the food culture of Vigia, although, in some cases, it is no longer the staple food consumed by many families. Among the students, the least favored foods are: pork dishes, beef liver and certain fish species.

About the fruit consumed by students, the most popular were: banana, orange, mango, watermelon, apple, grapes and acai berries. Thus, within the sample, there is a low consumption of fruits considered typical of the Amazon region; during the visit to the street fair, students had already found a limited sale of them, possibly because there is no largescale cultivation nearby, except of acai berry.

The answers to the questions freely prepared by students, revealed some relevant aspects to understand the food culture of the sample, which possibly reflects habits and customs of the community of Vigia, such as: comment about the ease of access to food markets in contrast to the amount of work that 
de ova de gurijuba; entrevistado 6 - 96 anos, nomeou diversos peixes que antes eram mais consumidos, comentou que a maniva era pilada manualmente, que as aves consumidas eram provenientes da criação em quintais, e que era mais fácil encontrar caranguejo, siri e turu para vender; entrevistado $7-71$ anos, respondeu que não há; entrevistado 8 - 61 anos, relatou que se comia caranguejo, siri e até turu ao sumo do coco; e entrevistado 9 - 69 anos, expôs a gurijuba salgada cozida no feijão, visto que hoje em dia, pelo fato de o peixe já ser congelado dentro das embarcações, é mais difícil encontrar esse peixe na forma salgada.

Sobre os relatos acima registrados, analisase a influência da indústria na alimentação, tanto com relação ao congelamento para conservação dos peixes priorizando assim a exportação, quanto na produção da maniva pré-cozida, com intuito de diminuir o tempo de cocção da folha tornando mais praticidade ao seu preparo. Uma relevante observação relaciona-se ao consumo de comidas típicas tradicionais, antes consideradas comidas para dias festivos, e hoje comercializadas em restaurantes e barracas de rua, vale ressaltar que as comidas citadas, embora a maniçoba e pato no tucupi tenham seu consumo em larga escala atrelados à festividade do Círio, são também mais consumidas fora dos dias de comemoração na atualidade.

Levantou-se o consumo no passado do beiju - tipo de pão preparado com farinha de mandioca - mas sabe-se que esse alimento ainda é habitual na dieta dos moradores da zona rural. Acredita-se que a popularização da tapioca ou tapioquinha como alimento e a expansão de sua comercialização pelo país tenha inspirado culinaristas e gastrônomos para preparação de recheios cada vez mais criativos, 0 entrevistado que levantou a questão, baseando-se nos exemplos de recheios citados redigidos na ficha (queijo, chocolate, leite condensado e ovo), talvez não tenha a dimensão das possibilidades culinárias já "inventadas" para o antes simples beiju de tapioca, servido singelamente com manteiga ou margarina na versão salgada ou com coco ralado e leite de coco na doce.

Com relação à terceira pergunta do roteiro "Na sua visão, quais são os alimentos mais consumidos nessa região?", seguem as respostas: entrevistado $1-78$ anos, identificou as carnes compradas em supermercado; entrevistado 2 - 78 anos, harvesting, husbandry and fishing took in the past. Today, and with a retirement pension, it is more convenient to buy food than to grow it.

The use of aluminum cookware stood out at the expense of clay pots, which would give a distinctive flavor to food; the transfer of knowledge about the typical food preparation as an important cultural heritage; the substitution of natural seasonings for processed spices; the strong belief that acai berries should not be ingested with other fruits; and the criticism of the "shortage" of food due to its price, in contrast with the "abundance" of the past.

During the development of the subject and the socialization of popular knowledge and information collected through the interviews, it was observed some changes, in recent decades, in the community's eating habits. These are due to financial reasons, to the dynamics of food supply or its overvaluation and also because of consumers' dietary restrictions, like respondents who commented not eating certain foods for health reasons, which can be considered normal; there was also mention to certain kitchen appliances that are no longer used and the emphasis on the more natural origin of the food consumed in the past; and it was also done a survey of local food culture.

While proposals for practical actions for the recovery of the typical cuisine, the most defended suggestions were: a systematic offer of regional cuisine on the menus of the city's restaurants and the organization of gastronomic events.

Among the challenges it was pointed out: the lack of interest of the Food and Drink industry, possibly because of the high cost of preparation of the main traditional ethnic foods, and because some of these foods are on offer in the street stalls, although the sanitary conditions are not favorable; and the lack of incentive by the government for this kind of events.

Another aspect discussed in the classroom, remaining for further consideration, is the individual position about the local cuisine, starting from the justification that the appreciation of the cultural heritage serves as knowledge, as well as historical record of experiences that "enable men to remember and increase the sense of belonging to the same space, sharing the same culture and develop the perception of a common set of elements, which provide the group with 
respondeu peixes; entrevistado 3 - 72 anos, citou carne, frango, e entre as frutas ressaltou o açaí; entrevistado 4 - 66 anos, disse peixe; entrevistado 5 - 69 anos, expôs peixes mais "sofisticados"; entrevistado 6 - 96 anos, respondeu frango, carne e feijão; entrevistado 7 - 71 anos, respondeu açaí, peixe, carne, frango, feijão e arroz; entrevistado $8-61$ anos, relatou carne e frango; e entrevistado $9-69$ anos, comentou carne e frango, por serem mais acessíveis financeiramente nos mercados, em detrimento do peixe.

Percebe-se na maioria das respostas há menção sobre a substituição do peixe pela carne vermelha e pelo frango, em vista da facilidade de acesso a esses alimentos nos mercados da cidade, e principalmente por questões financeiras, sendo assim, constatou-se que, no caso analisado, embora a cidade esteja situada às margens de um rio, o preço apresenta-se como fator limitante do consumo alimentar de peixes para os entrevistados; ainda que, empiricamente, observe-se que o valor de mercado praticado na comercialização de peixes naquela região seja menor comparado ao da capital, todavia, deve-se levar em consideração o poder aquisitivo da comunidade em questão.

\section{HÁBITOS ALIMENTARES}

Basicamente as perguntas de sondagem formuladas aos alunos foram: comida típica preferida; comida que mais comia no dia a dia; comida que não comia; e fruta que costumava comer. Traçando um paralelo entre as respostas anteriormente apresentadas e os relatos dos alunos a respeito de seus gostos e costumes alimentares, pôde-se concluir que não houve discrepância, a maioria apresentou que no cotidiano consome carne, frango, arroz e feijão; poucas referências ao consumo de legumes e verduras foram feitas; além das comidas típicas citadas ao longo do descritivo, de acordo com as respostas dos discentes, acrescentam-se mais duas: arroz paraense e arroz com galinha.

Com relação ao pescado, apontado pelos entrevistados como tipo de alimento mais escasso no presente em vista do aumento gradativo de custo, foi levantado por alguns alunos como parte integrante de suas refeições cotidianas, assim como na entrevista dos idosos, portanto, conclui-se que o peixe não deixou de fazer parte da cultura alimentar vigiense, apenas, em alguns casos, passou a meaning and form the collective identity." (Rodrigues, 2003 p.17).

Considering the presented framework, the proposed curriculum of the course in question and the planned objectives for the curriculum component, it is believed that the assessment activity, whose results have been described and analyzed above, has fulfilled the objectives of contributing for subsequent lessons, tracing a relationship between theory (scientific knowledge) and practice (empirical knowledge), and to approach the relevance of popular knowledge collected in the interviews, as idiosyncratic features inherent to the local culture.

\section{CONCLUSION}

During classes, several reports from the students (interviewers) served as basis for the development of the planned content, and to stimulate reflection on the eating habits of different generations within the same community. Despite the short time, it was possible to draw a parallel between past and present. The reported activity was considered the most relevant to approach the menu within the didactic-pedagogic proposal of the course.

The type of record performed is considered important to understand how some habits regarding food can undergo changes over time, although they are still known or/and practiced by a smaller group. Two foods were considered typical of the region by the interviewees, however unknown to the taste of most students, as follows: gurijuba fish cooked with beans and crab with coconut juice, both presented and tasted on the last day of school.

In addition to offer students a practical and dynamic way of learning by placing them in the role of citizen-students, social change actors, the activities enabled the realization that the knowledge acquired throughout their lives and their experiences are as relevant in their social and vocational training as scientific knowledge for planning and development of actions aimed at valuation of the heritage, and therefore its preservation.

The materials produced throughout the curriculum component: garland of recipes, menus of tasted recipes, photos of tasted dishes, interview scripts transcribed by students and record forms of the dynamic assessment of the curricular component are filed in the FIPA, in Vigia. 
não ser mais o principal alimento consumido por muitas famílias. Entre as restrições alimentares, por gosto, citadas pelos alunos estão: comidas preparadas com porco, bife de fígado e determinadas espécies de peixes.

Com relação às frutas consumidas pelos discentes, as mais comentadas foram: banana, laranja, manga, melancia, maçã, uva e açaí, assim constatou-se, dentro da amostra, um baixo consumo de frutas típicas consideradas características da região amazônica; na visita técnica realizada na feira livre, os discentes já haviam constatado deficiência na comercialização das mesmas, possivelmente em razão do não cultivo em larga escala das mesmas nas proximidades, com exceção ao açaí.

Das respostas às perguntas livres elaboradas pelos discentes, retirouse relatos considerados relevantes para entender a cultura alimentar da amostra, que possivelmente espelha hábitos e costumes da comunidade vigiense, seguem alguns apontamentos: comentário acerca da facilidade de acesso aos alimentos em mercados, visto que antigamente, tinham mais trabalho com - cultivo, a criação de animais e a pesca, e na atualidade, com auxílio da aposentadoria, seria mais prático comprar alimentos.

Destacou-se o uso de panelas de alumínio em detrimento das panelas de barro, que dariam sabor especialmente diferenciado à comida; o repasse do conhecimento sobre o modo de preparo de comidas típicas como importante herança cultural; a substituição de condimentos naturais por temperos industrializados; o reforço na crença da impossibilidade de consumo do açaí com outras frutas; e a crítica à "escassez" de alimentos em razão do preço, em contraponto à "fartura" do passado.

Durante o desenvolvimento da disciplina e a socialização dos saberes populares e informações coletadas através das entrevistas realizadas, pôde-se verificar algumas mudanças nos hábitos alimentares da comunidade nas últimas décadas por questões financeiras, em razão da dinâmica de oferta dos alimentos ou da supervalorização dos mesmos, e também por causa de restrições alimentares dos consumidores, a exemplo de entrevistados que comentaram não mais ingerir determinados alimentos por questão de saúde, o que pode ser considerado normal; houve também menção sobre o uso de determinados utensílios de cozinha que
The record of the experience of the I Gastronomic Competition Flavors of Vigia was done in format of a banner with the title "Theory and Practice in favor of the Amazon Cuisine Valorization", presented at the VIII Tourism Debate - Community-based Tourism: debating experiences and demystifying concepts, an unrecorded event, sponsored by the Faculty of Tourism of the Federal University of Pará (FUPA) on October 2012.

\section{REFERENCES}

Berkenbrock, V. J. (2009). Dinâmicas para encontros de grupo (8 ed.). Petrópolis: Vozes.

Ministério da Educação. Secretaria de Educação Profissional e Tecnológica. Catálogo Nacional de Cursos Técnicos. Retrieved September 24, 2014 from http:// portal.mec.gov.br/setec/arquivos/pdf3/ catalogo_tecnicos.pdf

Freire, P. (1996). Pedagogia da Autonomia: saberes necessários à prática educativa (33 ed.) São Paulo: Editora Paz e Terra.

IBGE - Instituto Brasileiro de Geografia e Estatística. Censo 2010. Retrieved October 8, 2014 from http://www. censo2010.ibge.gov.br/sinopse/index. php?dados $=29 \& u f=15$

IFPA - Instituto Federal de Educação, Ciência e Tecnologia Do Pará (2012). Proposta Pedagógica do Curso Técnico Subsequente em Turismo e Hospitalidade. Vigia: Campus Rural de Marabá/Polo Avançado de Vigia de Nazaré.

Mourão, K. R. M., Pinheiro, L. A., \& Lucena, F. (2007). Organização social e aspectos técnicos da atividade pesqueira no município de Vigia-Pa. Boletim do Laboratório de Hidrobiologia, 20(1), 3952.

Secretaria de Estado, Planejamento, Orçamento e Finanças. Estatística Municipal/ Vigia 2011. Retrieved October 2, 2014 from http://iah.iec.pa.gov.br/iah/ fulltext/georeferenciamento/vigia.pdf

Rodrigues, M. (2003). Preservar e consumir: o patrimônio histórico e o turismo. In: $P$. P. Funari \& J. Pinsky, J. (Orgs.). Turismo e patrimônio cultural (3 ed.) São Paulo: Contexto.

Silva, A. F. G. da. (2013). O currículo na práxis da educação popular: projeto pedagógico interdisciplinar - tema gerador via rede temática. In: M. M. Pernambuco \& I. A. de Paiva (Orgs.). Práticas coletivas na escola. Campinas: Mercado de Letras.

Teixeira, E. S., Bernartt, M. de L.; Trindade, G. A. (2008). Estudos sobre pedagogia da alternância no Brasil: revisão de literatura 
deixaram de ser utilizados no decorrer do tempo e ênfase sobre a origem mais natural dos alimentos consumidos no passado, além do levantamento de especificidades da cultura alimentar local.

Enquanto propostas de ações práticas em prol da valorização da culinária típica, as sugestões mais defendidas foram: a oferta regular de pratos relativos à culinária típica regional nos cardápios dos restaurantes do município e a realização de eventos gastronômicos.

Entre os desafios a serem enfrentados para a concretização dessas ações, apontouse: o desinteresse do empresariado do setor de Alimentos e Bebidas, possivelmente em razão do elevado custo de preparo das principais comidas típicas tradicionais, e pelo fato de algumas dessas comidas terem oferta constante em barraquinhas de rua da cidade, embora as condições sanitárias não sejam favoráveis; e a falta de incentivo por parte do poder público para esse tipo de evento.

Outro aspecto discutido em sala de aula, que fica como reflexão, é o posicionamento que cada indivíduo tece a respeito da culinária local, partindo-se da justificativa de que a valorização do patrimônio cultural serve de conhecimento, além de registro histórico de experiências vividas que "permitem aos homens lembrar e ampliar o sentimento de pertencer a um mesmo espaço, de partilhar uma mesma cultura e desenvolver a percepção de um conjunto de elementos comuns, que fornecem o sentido de grupo e compõem a identidade coletiva." (Rodrigues, 2003, p.17).

Considerando-se 0 referencial apresentado, a proposta curricular do curso em questão e os objetivos previstos para o componente curricular, acredita-se que a atividade avaliativa, cujos resultados foram acima descritos e analisados, cumpriu a função tanto de subsídio para as aulas posteriores, traçando relação entre teoria (conhecimento científico) e prática (conhecimento empírico), quanto de abordagem sobre a relevância dos saberes populares, levantados nas falas dos entrevistados, como diferenciais ímpares inerentes à cultura local.

\section{CONSIDERAÇÕES}

Ao longo das aulas, diversos relatos dos estudantes entrevistadores serviram de respaldo no desenvolvimento do conteúdo previsto, assim como para estimular a reflexão e perspectivas para a pesquisa. Educação e Pesquisa. São Paulo, 2(2), 227-242.

Wikipédia. Vigia. Retrieved October 19, 2014 from http://pt.wikipedia.org/wiki/ Vigia_\%28Par\%C3\%A1\%29 
sobre os hábitos alimentares de diferentes gerações dentro de uma mesma comunidade, ainda que em curto espaço de tempo, foi possível traçar um paralelo entre passado e presente. Considerou-se a atividade relatada, em especial, como a de maior relevância para a abordagem da ementa dentro da proposta didático-pedagógica do curso.

Considera-se o tipo de registro realizado importante para entender como alguns hábitos relativos à culinária podem sofrem modificações ao longo do tempo, embora não deixem de ser reconhecidos e/ou ainda sejam praticados por um grupo menor. Registrou-se duas comidas consideradas como típicas da região pelos entrevistados, todavia desconhecidas ao paladar de grande parte dos discentes, sendo elas: gurijuba cozida no feijão e caranguejo ao sumo do coco, ambas apresentadas e degustadas no último dia de aula.

Além de proporcionar aos discentes a apreensão do conhecimento de maneira prática e dinâmica, colocando-os no papel de cidadãos-alunos, atores de mudanças sociais, as atividades realizadas permitiram a percepção de que os conhecimentos adquiridos ao longo de suas vidas e suas vivências são tão relevantes em sua formação social e profissional quanto o conhecimento científico em prol do planejamento e desenvolvimento de ações que visem à valorização patrimonial, e por consequência sua preservação.

Os materiais produzidos ao longo do componente curricular: cordel de receitas, cardápios das receitas degustadas, fotos dos pratos degustados, roteiros de entrevistas transcritas pelos alunos e fichas da dinâmica de avaliação do componente curricular encontram-se arquivados no atualmente IFPA/Campus Avançado Vigia.

O registro da vivência relativa ao I Concurso Gastronômico Vigia dos Sabores foi realizado em formato de banner, com o título "Teoria e Prática em prol da Valorização da Culinária Amazônica", apresentado durante o VIII Turismo em Debate - Turismo de base comunitária: debatendo experiências e desmistificando conceitos, evento sem anais, promovido pela Faculdade de Turismo da Universidade Federal do Pará (UFPA), campus Belém, no mês de outubro de 2012.

\section{REFERÊNCIAS}

Berkenbrock, V. J. (2009). Dinâmicas para encontros de grupo (8 ed.). Petrópolis: 
Vozes.

Ministério da Educação. Secretaria de Educação Profissional e Tecnológica. Catálogo Nacional de Cursos Técnicos. Recuperado em 24 de setembro de 2014, de http:// portal.mec.gov.br/setec/arquivos/pdf3/ catalogo_tecnicos.pdf

Freire, P. (1996). Pedagogia da Autonomia: saberes necessários à prática educativa (33 ed.) São Paulo: Editora Paz e Terra.

IBGE, Instituto Brasileiro de Geografia e Estatística. Censo 2010. Recuperado em 08 de outubro de 2014, de http://www. censo2010.ibge.gov.br/sinopse/index. php? dados $=29 \&$ uf $=15$

IFPA, Instituto Federal de Educação, Ciência e Tecnologia Do Pará (2012). Proposta Pedagógica do Curso Técnico Subsequente em Turismo e Hospitalidade. Vigia: Campus Rural de Marabá/Polo Avançado de Vigia de Nazaré.

Mourão, K. R. M., Pinheiro, L. A., \& Lucena, F. (2007). Organização social e aspectos técnicos da atividade pesqueira no município de Vigia-Pa. Boletim do Laboratório de Hidrobiologia, 20(1), 3952.

Secretaria deEstado, Planejamento, Orçamento e Finanças. Estatística Municipal/ Vigia 2011. Recuperado em 02 de outubro de 2014, de http://iah.iec.pa.gov.br/iah/ fulltext/georeferenciamento/vigia.pdf

Rodrigues, M. (2003). Preservar e consumir: o patrimônio histórico e o turismo. In: $P$. P. Funari \& J. Pinsky, J. (Orgs.). Turismo e patrimônio cultural (3 ed.) São Paulo: Contexto.

Silva, A. F. G. da. (2013). O currículo na práxis da educação popular: projeto pedagógico interdisciplinar - tema gerador via rede temática. In: M. M. Pernambuco \& I. A. de Paiva (Orgs.). Práticas coletivas na escola. Campinas: Mercado de Letras.

Teixeira, E. S., Bernartt, M. de L.; Trindade, G. A. (2008). Estudos sobre pedagogia da alternância no Brasil: revisão de literatura e perspectivas para a pesquisa. Educação e Pesquisa. São Paulo, 2(2), 227-242.

Wikipédia. Vigia. Recuperado em 19 de outubro de 2014, de http://pt.wikipedia. org/wiki/Vigia_\%28Par\%C3\%A1\%29

\section{ENDNOTES}

1 Peixe característico do município. 
ANEXO / APPENDIX

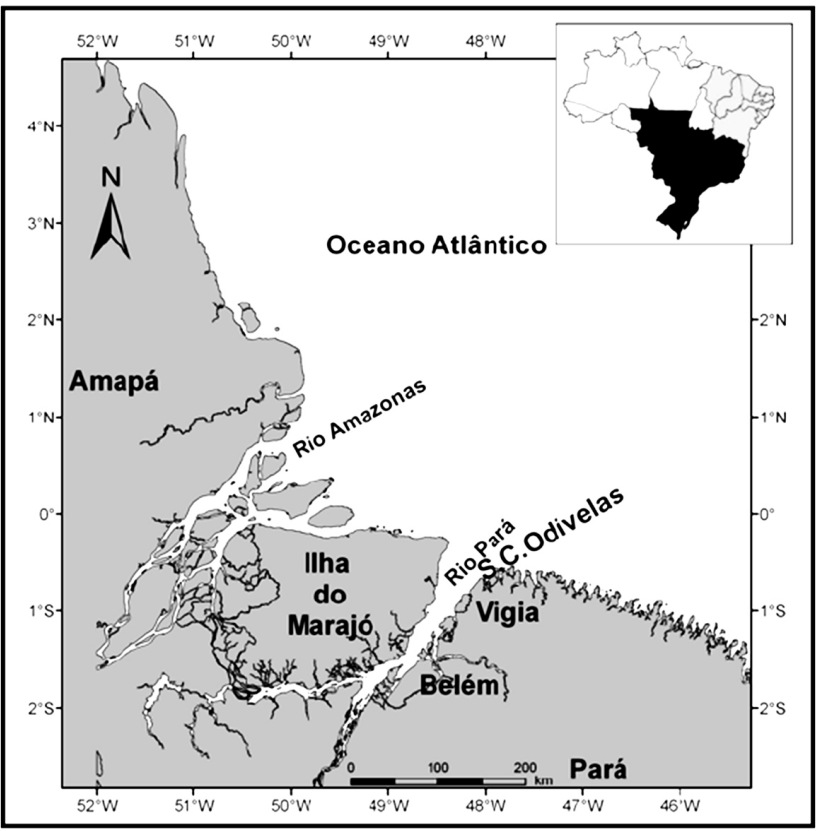

Figura 1 - Mapa de localização de Vigia-PA. Fonte: (Mourão; Pinheiro; \& Lucena, 2007, p. 41).

Figure 1 - Vigia-PA Location Map. Source: (Mourão; Pinheiro; \& Lucena, 2007, p. 41).

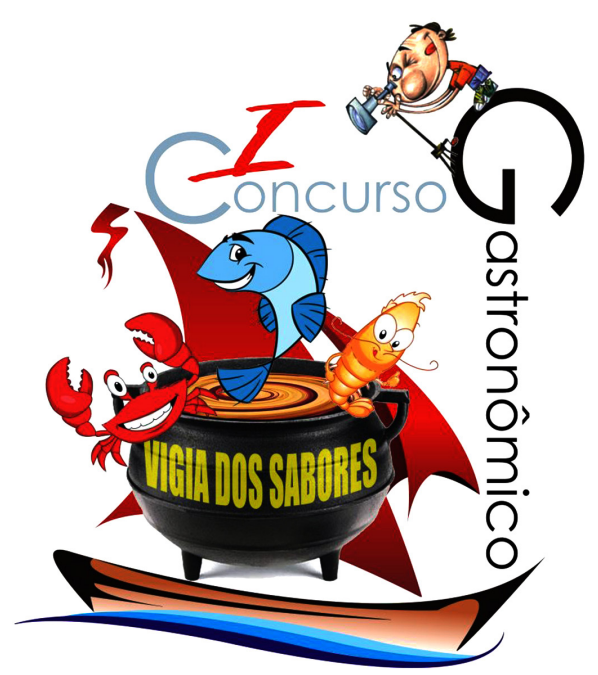

Figura 2 - Logomarca do I Concurso Gastronômico Vigia dos Sabores. Fonte: arquivo pessoal da docente do componente curricular.

Figure 2 - Logo of the I Gastronomic Competition Flavors of Vigia. Source: Personal archive of the teacher of the curriculum component.

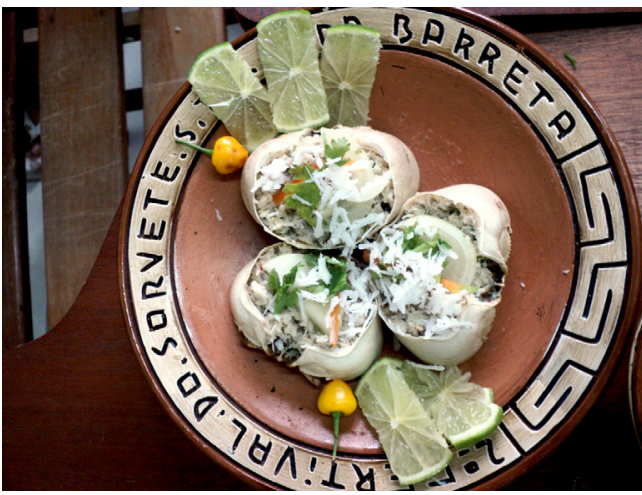

Figura 3 - Caranguejo ao sumo do coco. Fonte: arquivo pessoal da docente do componente curricular.

Figure 3 - Crab with coconut juice. Source: Personal archive of the teacher of the curriculum component. 